\title{
Promoting the empowerment of Young Saudi Women through digital art Events in Light of the Kingdom of Saudi Arabia's 2030
}

\author{
Abdulaziz R. Alamro \\ Curriculum and Instruction Associate Professor \\ College of Education- Ha'il University \\ Ha'il University, 81481 \\ Hail, KSA \\ Nancy A. Elsawy \\ Textile Design Assistant Professor \\ College of Education- Ha'il University \\ Assistant professor, Faculty of specific education \\ Tanta University, Egypt
}

\author{
Nouf A. Alsuwaida \\ Educational Learning Technology in Art and Design \\ Assistant Professor, Ha'il University \\ Hail, KSA \\ Usama M. Ibrahem \\ Educational Technology Associate Professor \\ College of Education- Ha'il University \\ Assistant professor, Faculty of Ismailia education, \\ Suze Canal University, Egypt
}

Received: January 12, 2021. Revised: March 23, 2021. Accepted: April 1, 2021. Published: April 7, 2021.

\begin{abstract}
- this study aimed to investigate the notion of empowerment of young Saudi women to in digital arts activities in light of the development strategy within the framework of the Kingdom's 2030 Vision. It investigated building a digital art system that attracts young women's minds and skills in support of the digital transformation process in the art field to increase the sustainability of specific job opportunities as well as the percentage of women's participation in governmental and private sectors. The study employed the survey and Delphi methods, and two rounds of questionnaires were conducted as part of the data collection process. The results of this study tend to indicate that young Saudi women can be empowered through the use of digital art, and increasing their efficiency through education while allowing time for the training process.
\end{abstract}

Keywords: empowering young women, digital arts, Vision 2030, Saudi Arabia

\section{i. INTRODUCTION}

E MPOWERING women has become one of the strategies of the Kingdom of Saudi Arabia in the era of King Salman bin Abdulaziz and Crown Prince Mohammed bin Salman in April 2016, with supporting for women in all different fields (Vision 2030). Consequently, this present time is an important historical stage in the life of Saudi women.

*ACKNOWLEDGMENTS

The authors extend their appreciation to the Deputy for research and Innovation, Ministry of Education in Saudi Arabia for funding this research work through the project number SS-153 (through the initiative of social sciences number of the contract).
Saudi women represent almost $50 \%$ of the total population; therefore, if women enhance their participation, get empowered, compete, it would increase the domestic economic activity [1].'Some relevant studies can be found in [2];[3].

Saudi women increasingly seek to become active members of society, where their roles are defined in terms of what they can offer for their country's economic, social, and cultural development. In this regard, Saudi Vision 2030 supports the wealth and potential that lies in the ambition of Saudi people and the potential of both genders, especially among younger generations, to build a thriving economy through establishing an educational system able to cope with market needs [4]. Hence, empowering women can have the potential to increase the competitiveness of the Saudi economy with a view to increasing foreign economic integration [5].

A study indicated that some Saudi women own their businesses, noting that Saudi women possess a perception of self-sufficiency [6], which they believe or perceive to perform or produce. Prior work experience from home, education, and study abroad allowed some women to gain self-confidence and recognize their talents and desires. In other word, Saudi women must participate in the development of the country, which requires improving their capabilities in knowledge and enhancing their self-confidence and ability to work in digital arts in the public and private sectors. Also, as women are considered as partners with men in the development and advancement of the Saudi society, they should be able to obtain appropriate opportunities to build their future, rely on themselves, and obtain their rights; this constitutes an essential element in the development of society [7];[8].

Moreover, technology has become an integral part of the 
lives of many around the world because its use saves time and effort not only in daily life, but also in the teaching and learning of various disciplines, including the arts. Hence, technology has entered various fields of practical and theoretical science and also the arts, such as painting, sculpture, ceramics, design, and even drama. Hence there have been many developments in terms of the intersection of technology and art. Each of these arts had unique experiences with technology, so the so-called digital art field, also known as art technology or digital arts, that use the computer tools [9]. Thus, based on these premises, this study seeks to investigate the possible ways to empower young Saudi women to compete in digital arts activities in light of the development strategy within the framework of the Kingdom's 2030 Vision. In doing so, the study investigates the growth of a digital art system that attracts young women's minds and develops their skills in support of the digital transformation process in the arts.

\section{ii. LITERATURE REVIEW}

The literature review focuses on three aspects which are relevant to the study. First, in this paper we review the literature pertaining to the notion of women empowerment within the framework of the Saudi Vision 2030. Then, the article discusses the field of digital arts with particular reference to the Kingdom of Saudi Arabia (KSA) and finally we shed light on the various technological drawing tools.

\section{- Empowering women in Saudi Vision 2030}

The Saudi government supports women in all different fields, which is an important historical stage in the lives of Saudi women. Using technology has changed the Saudi culture and society, often to a positive degree, especially for women. As a result, both genders have become more self-confident, open-minded, and are more likely to communicate with each other [10].

The use of online communities, in a country where Islam acts as a primary force in determining social norms, values, and practices, is disrupting long- established traditions, enabling the mixing of members of both sexes, and making people aware of different ways of living.

To that end, the Saudi government has made a considerable effort to promote gender equality and ensure women's equal access to education and job opportunities. The education sector of the Kingdom of Saudi Arabia is passing through a new era for women because of its young and growing population and prospering knowledge-based industry.

Women's work has become a social necessity for favorable economic conditions and societal development. The main reason for the move of Saudi women from the home to the work environment is to increase their family income, achieve financial independence and a more secure future. The empowerment of Saudi women has not been limited to education but also extended to the professional field. In this respect:

Only $14.4 \%$ of Saudi women currently participate in the workforce, the lowest rate in the region, and $78.3 \%$ of unemployed women hold university degrees. The government hires women, predominantly in education $(85 \%)$, but as yet, the private sector generally does not. Only $5 \%$ of jobs currently held by women are in the private sector." [11].

Despite these statistics, there is a relationship between empowering young women and the economic growth in Saudi Arabia according to the Vision 2030. The results of studies have indicated that there was a significant positive relationship between the growth of the Saudi economy and women empowerment [1];[12];[13]. Moreover, using technology in art can provide new job opportunities for Saudi women in the labor market. For example, digital art as a new field of technology represents an opportunity for young Saudi women who wish to become designers in private companies or in their own businesses. Digital art can help all artists in different art fields, such as graphic design, internet design, or fashion design.

\section{- Digital arts}

Digital art is a kind of amalgamation between artistic creativity and scientific creativity, in which the artist relies on the use of digital media such as the computer as an artistic tool to convey a specific message whose language is sense and creativity, which is a broad term that includes artistic works and practices by using digital technology in professional ways, and making it an important element to develop a concept [14].

creativity. Since the seventies, digital art has become a prominent method of modern media, and nowadays, with the development of technology and the availability of various digital design programs, digital art has become one of the latest types of visual art [15].

digital art defined as art created mechanically using a computer-based template [16]. In digital art, the entire image is usually made on a computer, and sometimes, a handcrafted image can be scanned onto a computer to give it a modern look or add a finishing touch. Other forms of digital art include animation, computer games, and virtual 3D sculpture displays, as a result, digital art forms can be observed almost everywhere nowadays [9]; [17]; [18] and [19].

The use of technology in art allows artists to display their art the way they desire. Through digital art, artists can create and enhance artwork by adding, for example, sounds and other elements. In addition, the spread of technology in art has made it more accessible for potential artists to explore their wildest ideas and present them to the world. As a result, a great number of art exhibitions just focus on digital art around the 
world, such as Ars Electronica [20]. In present days, artists often use technology to sell a well as discuss their work with their audience.

\section{- Technology drawing tools}

- Drawing tools software

Several software are commonly used by designers to create digital art, but this study will mainly focus on specific ones. The most popular and user friendly software's often used for creating digital art are Photoshop ${ }^{\mathrm{TM}}$ and Painter ${ }^{\mathrm{TM}}$. Both software programs help artists to quickly create, edit, and manipulate images the using custom artist tools. In Adobe Photoshop ${ }^{\mathrm{TM}}$, for example, a wide range of tools can be used, such as brushes, styles, filters and a wide color range, which allow digital artists to create art in high standards [21].

Furthermore, Affinity DesignerTM is another well-known program that allows the designer to create artwork by using different tools and options such as the one million plus percent zoom, brush stabilization options, advanced blend modes, and precise control over curves. This software is usually used by art designers to create items such as icons, pattern designs, illustrations, concept art, and web graphic. Moreover, digital art softwares are not just limited to graphic artwork. In fact, certain softwares replicate real-life painting impressions. Rebelle $^{\mathrm{TM}}$, for instance, has become of one of the most famous software programs in the digital art world because it is designed with the functionality of replicating and emulating how colors behave in real life [21]. Rebelle ${ }^{\mathrm{TM}}$ gives the impression that the image is developed using real watercolor.

\section{- Devices used for digital art}

For many digital artists around the world, the iPad Pro is quickly becoming the primary device. This device allows the designer to create art on the tablet using different drawing tools and applications [22]. The iPad Pro is a new device that comes with a digital pencil that can be used to create artworks. Adobe Creative Suite 6 Design Standard ${ }^{\text {TM }}$ (CS6) is a software application that artists can use in their drawing and sketching on the iPad Pro. Although Adobe Creative Suite 6 Design Standard is a rather new software, artists often need the help of professionals to teach them how to use the program [23]. Another device widely used by designers is the Surface Pen. Using this technology, designers can easily sketch out and edit their work and at the same time [24]. In addition, the Surface Pen gives designers a real-life artwork experience as it allows them to draw on paper with a traditional pencil. The Surface Pen has also been designed in such a realistic as it has a tip on one end and a rubber eraser on the other end.

Furthermore, the Microsoft Surface Pro 7 laptop is becoming the first option for many illustrators, graphic designers, and vector artists around the world as this device enables them to draw on Procreate, just like on the Apple iPad, and because it saves time and does not require a hardware upgrade. It can also be used with a digital pen, attached to its side; to draw, designers simply have to flatten the screen and use it as a drawing for sketching, and creating digital art. The Microsoft Surface Pro 7 laptop pen is much appreciated by its users as it is much balanced and sturdy and also provides a good grip.

\section{- Websites, blogs, and mobile apps}

Artists use different digital tools such as websites, blogs, and mobile apps for drawing, sketching, learning by using activity games, selling and buying via online stores, and watching videos via online platforms. Also, digital portfolios and websites are particularly important for artists because they need this for their future careers as professional artists [23].

As a result of the lack of research investigating ways to empower young Saudi women in digital arts activities in light of the development strategy within the framework of the Kingdom's 2030 Vision, this study raised the following research questions:

1. What is the general trend in terms of digital arts use by young Saudi women?

2. What are the community contributions that enable young Saudi women to obtain an appropriate income from digital arts?

3. What are the challenges that hinder young Saudi women's work and empowerment in the field of digital arts?

4. What are the most important economic benefits that can be gained from empowering young Saudi women in digital arts?

\section{iii. METHODOLOGY}

- Research design

The research was mix method which include quantitative and qualitative approaches.

- Sampling

This study's participants included female students at one university and also faculty experts in different universities in field of Art and Design in the Kingdom of Saudi Arabia (KSA). The sample of the research was random sampling by selecting both the female students and the faculty experts.

\section{- Student participants}

The participants of this study included art and design female students. The target population was composed of the 167 graduates of the Department of Art Education at one university in Saudi Arabia, and the sample represented $20 \%$ of the total population. As a result, the sample size reached 35 graduates of art education.

\section{- Selection of faculty experts}

The Delphi method used as a survey design technique, was composed of faculty from both genders' specialists and experts in the field of art. The faculty was composed of university professors, educators, as well as amateur artists in digital art in the KSA. The sample was composed of 15 participants holding different positions in higher education such as full professors, associate professors, and assistant professors. Their experience in higher education was as follows: $80 \%$ had more than fifteen years of experience, $13 \%$ from ten to less than fifteen years, 
$6.6 \%$ had less than ten years of experience while $6.6 \%$ of them had less than five years of experience in higher education. There were $60 \%$ of males and $40 \%$ of females with different experiences with digital arts. Their fields of expertise included art education, curriculum and instructions in art education, drawing and arts, fashion design and textiles, digital design, history of fashion and embroidery, history of fashion, arts criticism, philosophy of design and advertising, and technical art printing.

- Ethical considerations

The researchers sent the research proposal to the university committee's research ethics and got approval before beginning the research. Participants sign agree or disagree in the consent letter if they want to participate in the study. All information is used for research purposes.

\section{- Data collection and analysis}

- Students questionnaire

The questionnaire was administered among 35 graduates of art education, one university in KSA selected from the target population, as highlighted above. The questionnaire was created using the Arabic language as the graduates' mother language and then translated to English. The questionnaire was presented to a group of specialists to formulate the item statements; amendments were made according to the percentage of their agreement to the questionnaire items using the Cooper formula. The agreement rate ranged between $81.8 \%$ to $100 \%$, which is an acceptable percentage.

The first research question was investigated using a Google form. The survey investigated the attitude of female graduates to work in digital art as one of the areas of work for Saudi women according to the Kingdom's vision 2030. In addition, the survey explored the participants' views and suggestions about how to enable Saudi women to reach university in the in the field of digital arts.

The questionnaire was included 12 items in the form of statement and aimed to measure the responses, using a fivelevel Likert scale as follows: strongly agree (counted as five points), agree (four points), to somewhat agree extent (3 points), disagree (two points) and strongly disagree which counted as one point. All data were computed and analyzed using the Statistical Package for the Social Sciences (SPSS) version 23 .

Table 1

Validation of the internal consistency of the questionnaire

\begin{tabular}{|c|c|c|c|c|c|c|}
\hline Phrase & $\mathbf{1}$ & $\mathbf{2}$ & $\mathbf{3}$ & $\mathbf{4}$ & $\mathbf{5}$ & $\mathbf{6}$ \\
\hline Correlation coefficient & $* * 0.479$ & $* * 0.481$ & $* * 0.547$ & $* 0.303$ & $* * 0.462$ & $* * 0.432$ \\
\hline Items & $\mathbf{7}$ & $\mathbf{8}$ & $\mathbf{9}$ & $\mathbf{1 0}$ & $\mathbf{1 1}$ & $\mathbf{1 2}$ \\
\hline Correlation coefficient & $* * 0.393$ & $* 0.297$ & $* * 0.502$ & $* 0.393$ & $* * 0.462$ & $* * 0.432$ \\
\hline
\end{tabular}

It is clear from Table 1 above that the correlation coefficient of each of the items with the general degree of the questionnaire is a statistically significant function at the level of significance 0.01 and 0.05 , which confirms the validity of the internal consistency. Secondly, the reliability of the questionnaire used Cronbach's alpha and mid-point parameters, as illustrated in Table 2 below

Table 2

Cronbach's alpha factor

\begin{tabular}{|c|c|}
\hline Number of items & Alpha Factor \\
\hline 12 & 0.754 \\
\hline
\end{tabular}

From the previous table, it is clear that the value of Cronbach's alpha coefficient is acceptable, which indicates the reliability of the questionnaire.

Table 3

Split-half coefficient

\begin{tabular}{|c|c|c|}
\hline Number of items & $\begin{array}{c}\text { Spearman } \\
\text { Factor }\end{array}$ & $\begin{array}{c}\text { Gitman's } \\
\text { Factor }\end{array}$ \\
\hline 12 & 0.796 & 0.789 \\
\hline
\end{tabular}

It is apparent from the previous table that the value of the values of the Gitman's coefficient and the Spearman coefficient are statistically acceptable, indicating the reliability of the questionnaire. Statistical analysis of the results of the questionnaire was performed using frequencies and percentage t-tests.

Table 4

The relative distribution of the study sample according to its demographic characteristics

\begin{tabular}{|c|c|c|c|}
\hline Variables & Class & Number & Percentage \\
\hline \multirow{2}{*}{ Age } & $19-23$ & 21 & $60 \%$ \\
\hline & $24-27$ & 14 & $40 \%$ \\
\hline \multirow{2}{*}{$\begin{array}{l}\text { Marital } \\
\text { status }\end{array}$} & Single & 20 & $57.1 \%$ \\
\hline & Married & 15 & $88.6 \%$ \\
\hline \multirow[t]{2}{*}{ Occupation } & $\begin{array}{l}\text { Do not } \\
\text { work }\end{array}$ & 31 & $88.6 \%$ \\
\hline & Working & 4 & $11.4 \%$ \\
\hline \multirow{2}{*}{$\begin{array}{l}\text { Participation } \\
\text { in } \\
\text { specialized } \\
\text { societies - } \\
\text { cultural } \\
\text { clubs - } \\
\text { permanent }\end{array}$} & $\begin{array}{l}\text { Not } \\
\text { Participate }\end{array}$ & 28 & $80 \%$ \\
\hline & Participate & 7 & $20 \%$ \\
\hline
\end{tabular}


INTERNATIONAL JOURNAL OF EDUCATION AND INFORMATION TECHNOLOGIES

\begin{tabular}{|l|l|l|l|}
\hline exhibitions & & & \\
\hline $\begin{array}{l}\text { Apply for } \\
\text { national }\end{array}$ & $\begin{array}{l}\text { Not } \\
\text { Participate }\end{array}$ & 18 & $51.4 \%$ \\
\hline
\end{tabular}

\begin{tabular}{|l|l|l|l|}
\hline competitions & Participate & 17 & $48.6 \%$ \\
\hline
\end{tabular}

Table 5

Study sample responses to the questionnaire on the trends of art education graduates to work in the field of digital art

\begin{tabular}{|c|c|c|c|c|c|c|c|c|c|c|c|}
\hline \multirow{2}{*}{ No. } & \multirow{2}{*}{ Items } & \multicolumn{2}{|c|}{$\begin{array}{c}\text { Strongly } \\
\text { Agree }\end{array}$} & \multicolumn{2}{|c|}{ Agree } & \multicolumn{2}{|c|}{$\begin{array}{c}\text { To somewhat } \\
\text { agree extent }\end{array}$} & \multicolumn{2}{|c|}{ Disagree } & \multicolumn{2}{|c|}{$\begin{array}{l}\text { Strongly } \\
\text { disagree }\end{array}$} \\
\hline & & No. & $\%$ & No. & $\%$. & No. & $\%$ & No. & $\%$ & No. & $\%$ \\
\hline 7 & $\begin{array}{l}\text { I feel self-confident while working } \\
\text { in digital arts. }\end{array}$ & 25 & $71.4 \%$ & 6 & $17.1 \%$ & 4 & $11.4 \%$ & - & - & - & - \\
\hline 1 & $\begin{array}{l}\text { I'm very excited about working in } \\
\text { digital arts. }\end{array}$ & 24 & $68.6 \%$ & 5 & $14.3 \%$ & 6 & $17.1 \%$ & - & - & - & - \\
\hline 10 & $\begin{array}{l}\text { I feel my real ability to make a } \\
\text { difference in society through my } \\
\text { work in the field of digital art. }\end{array}$ & 23 & $65.7 \%$ & 10 & $28.6 \%$ & 2 & $5.7 \%$ & - & - & - & - \\
\hline 3 & $\begin{array}{l}\text { I feel equal to men in the } \\
\text { performance of digital art. }\end{array}$ & 22 & $62.9 \%$ & 11 & $31.4 \%$ & 1 & $2.9 \%$ & 1 & $2.9 \%$ & - & - \\
\hline 5 & $\begin{array}{l}\text { Self-motivation is the main goal of } \\
\text { digital art. }\end{array}$ & 19 & $54.3 \%$ & 13 & $37.1 \%$ & 3 & $8.6 \%$ & - & - & - & - \\
\hline 12 & $\begin{array}{l}\text { I make a positive impression on } \\
\text { anyone who wants to work in the } \\
\text { digital art business. }\end{array}$ & 19 & $54.3 \%$ & 11 & $31.4 \%$ & 5 & $14.3 \%$ & - & - & - & - \\
\hline 2 & $\begin{array}{l}\text { The digital arts system is adapted to } \\
\text { the nature of the social environment } \\
\text { in which Saudi women live. }\end{array}$ & 17 & $48.6 \%$ & 14 & $40 \%$ & 4 & $11.4 \%$ & - & - & - & - \\
\hline 9 & $\begin{array}{l}\text { My studies helped me hone my } \\
\text { talent in digital art. }\end{array}$ & 16 & $45.7 \%$ & 12 & $34.3 \%$ & 4 & $11.4 \%$ & - & - & 3 & $8.6 \%$ \\
\hline 4 & $\begin{array}{l}\text { Working in digital art gives me a } \\
\text { great deal of independence. }\end{array}$ & 13 & $37.1 \%$ & 16 & $45.7 \%$ & 5 & $14.3 \%$ & 1 & $2.9 \%$ & - & - \\
\hline 6 & $\begin{array}{l}\text { The main goal of digital art is to } \\
\text { achieve financial income. }\end{array}$ & 8 & $22.9 \%$ & 11 & $31.4 \%$ & 12 & $34.4 \%$ & 4 & $11.4 \%$ & - & - \\
\hline 8 & $\begin{array}{l}\text { My husband and my family support } \\
\text { my work in the field of digital arts. }\end{array}$ & 7 & $20 \%$ & 11 & $31.4 \%$ & 13 & $37.1 \%$ & 2 & $5.7 \%$ & 2 & $5.7 \%$ \\
\hline 11 & $\begin{array}{l}\text { I feel pressure while working in the } \\
\text { digital art business. }\end{array}$ & 2 & $5.7 \%$ & 11 & $31.4 \%$ & 5 & $14.3 \%$ & - & - & - & - \\
\hline
\end{tabular}


Table 6

Independent sample tests depending on age and trends

\begin{tabular}{|c|c|c|c|c|c|c|c|c|c|}
\hline & $\begin{array}{r}\text { Lev } \\
\text { Tes } \\
\text { Equa } \\
\text { Varis }\end{array}$ & $\begin{array}{l}\text { fe's } \\
\text { for } \\
\text { ty of } \\
\text { ces }\end{array}$ & & & T-te & for Equ & ity of Means & & \\
\hline & $F$ & Sig. & $\mathbf{t}$ & df & $\begin{array}{l}\text { Sig. } \\
(2- \\
\text { taile }\end{array}$ & $\begin{array}{l}\text { Mean } \\
\text { Differ }\end{array}$ & $\begin{array}{l}\text { Std. Error } \\
\text { Difference }\end{array}$ & $\begin{array}{r}\text { Cor } \\
\text { Inter } \\
\text { Dif }\end{array}$ & $\begin{array}{l}\text { \% } \\
\text { dence } \\
\text { I of the } \\
\text { rence }\end{array}$ \\
\hline & & & & & & & & $\begin{array}{c}\text { Low } \\
\text { er }\end{array}$ & Upper \\
\hline $\begin{array}{c}\text { Equal } \\
\text { variances } \\
\text { assumed }\end{array}$ & .229 & $\begin{array}{c}.63 \\
6\end{array}$ & .485 & 33 & .631 & $\begin{array}{c}.9047 \\
6\end{array}$ & 1.86631 & $\begin{array}{c}- \\
2.89228\end{array}$ & $\begin{array}{c}4.7018 \\
1\end{array}$ \\
\hline $\begin{array}{c}\text { Equal } \\
\text { variances } \\
\text { not } \\
\text { assumed }\end{array}$ & & & .483 & $\begin{array}{c}27.70 \\
3\end{array}$ & .633 & $\begin{array}{c}.9047 \\
6\end{array}$ & 1.87244 & 2.93262 & $\begin{array}{c}4.7421 \\
4\end{array}$ \\
\hline
\end{tabular}

The previous table demonstrates that no statistically significant differences were found in the trends of graduates to work in the field of digital art according to the age group.

Table 7

Independent sample tests depending on the marital status

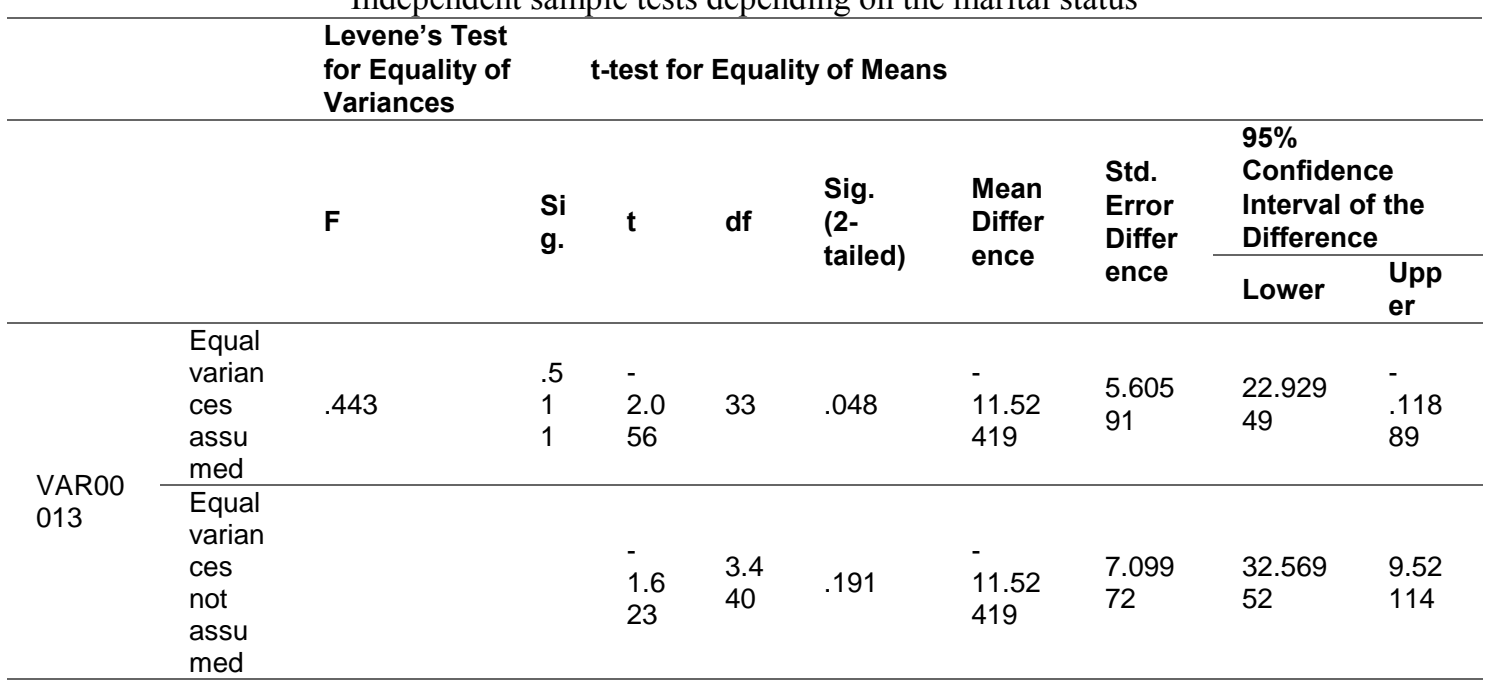

The above table shows that there are statistically significant differences between the average graduates' scores on the digital art trend questionnaire, depending on the marital status, where the value of $t$, which is a statistically significant value at 0.05 , in single women was 2.056 , averaged 44.77 compared to 33.25 for single women. The rise of the trend towards digital work is higher for single graduates than married graduates. This result may be consistent with the cultural norms in the most parts of Saudi Arabia where married men generally prefer the wife not to work.

Table 8

Independent sample tests depending on the profession

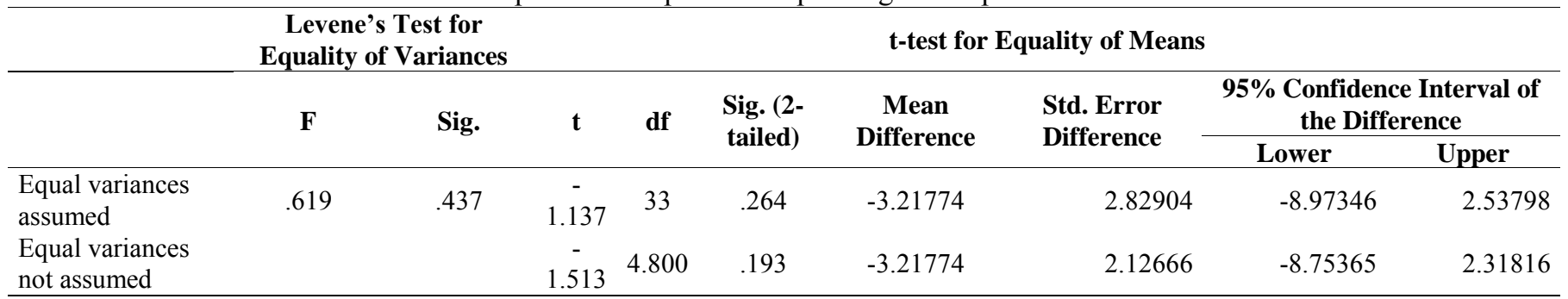


The previous table shows that there are no statistically significant differences in the trends of graduates to work in the field of digital art according to the profession.

Table 9

Independent sample tests depending on the participation in exhibitions or cultural clubs Levene's test for equality of variances T-test for equality of means

\begin{tabular}{lccccccrr}
\hline & F & Sig. & T & DF & $\begin{array}{c}\text { Sig. (2- } \\
\text { tailed) }\end{array}$ & $\begin{array}{c}\text { Mean } \\
\text { Difference }\end{array}$ & $\begin{array}{c}\text { Std. Error } \\
\text { Difference }\end{array}$ & $\begin{array}{c}\text { 95\% Confidence Interval of } \\
\text { the Difference }\end{array}$ \\
\hline $\begin{array}{l}\text { Equal variances } \\
\text { assumed }\end{array}$ & .367 & .549 & .296 & 33 & .769 & .67857 & 2.29084 & -3.98218 \\
$\begin{array}{l}\text { Equal variances not } \\
\text { assumed }\end{array}$ & & & .290 & 9.010 & .779 & .67857 & 2.34193 & -4.61834 \\
\hline
\end{tabular}

From the results presented in the previous table, it can be inferred that there are no statistically significant differences in the trends of female graduates to work in the field of digital art according to their participation in exhibitions or cultural clubs.

Table 10

Independent sample tests depending on the participation in competitions

\begin{tabular}{|c|c|c|c|c|c|c|c|c|c|c|}
\hline & & \multicolumn{2}{|c|}{$\begin{array}{l}\text { Levene's Test for } \\
\text { Equality of } \\
\text { Variances }\end{array}$} & \multicolumn{7}{|c|}{ t-test for Equality of Means } \\
\hline & & \multirow[t]{2}{*}{$\mathbf{F}$} & \multirow[t]{2}{*}{ Sig. } & \multirow[t]{2}{*}{$\mathbf{t}$} & \multirow[t]{2}{*}{ df } & \multirow[t]{2}{*}{$\begin{array}{l}\text { Sig. (2- } \\
\text { tailed) }\end{array}$} & \multirow[t]{2}{*}{$\begin{array}{c}\text { Mean } \\
\text { Difference }\end{array}$} & \multirow[t]{2}{*}{$\begin{array}{l}\text { Std. Error } \\
\text { Difference }\end{array}$} & \multicolumn{2}{|c|}{$\begin{array}{l}95 \% \text { Confidence Interval } \\
\text { of the Difference }\end{array}$} \\
\hline & & & & & & & & & Lower & Upper \\
\hline VAR00013 & $\begin{array}{l}\text { Equal variances } \\
\text { assumed }\end{array}$ & 1.710 & .200 & 3.496 & 33 & .001 & -16.16667 & 4.62448 & -25.57524 & -6.75809 \\
\hline
\end{tabular}

It is clear from the previous table that there are significant differences between the averages scores of graduates on the digital art trend questionnaire according to the participation in competitions, where the value of $t$, which is a statistically function value at 0.01 in favor of participants in national competitions, was 03496 and the average score of participants in national competitions was 45.76 versus 29.60 for nonparticipants in competitions.

Table 11

Summary of female students' attitudes towards digital art

\begin{tabular}{|cccc|}
\hline \multicolumn{3}{|c|}{ Trends } \\
\hline \multicolumn{2}{|c|}{ Positive } & \multicolumn{2}{c|}{ Negative } \\
\hline Number & Percentage & Number & Percentage \\
\hline 29 & $82.9 \%$ & 6 & $17.1 \%$ \\
\hline
\end{tabular}

Faculty expert's questionnaire

The second, third, and fourth research questions were investigated using the Delphi technique that consisted of two rounds of data collection and analysis using SPSS. The estimated span of the iterative data collection rounds was four months, starting with the first round in April 2020 and ending with the last round in July 2020.
Design of the first round of the questionnaire based on the literature review

The data for the second research question were collected using a Google form designed with two main sections. The first section gathered expert participants' demographic information, and the second section contained closed questions developed around three main themes. The questionnaire included ten closed questions and one open-ended item.

The three main themes around which the questionnaire items were developed were: (a) the reality of qualifying and training Saudi women in the field of digital arts, (b)the most important challenges facing the empowerment of Saudi women in the field of digital art, and (c)the most important recommendations and measures to empower Saudi women in digital art. Each theme contained ten items in the form of statements. The items were measured using a five-point Likert scale where participants expressed their agreement with the statements as follows: strongly agree, agree, uncertain, strongly disagree and disagree. Each theme also contained one open-ended question so that faculty participants could add any important information to empower the Saudi women in digital arts.

Results of the first round

The researchers analyzed the data using SPSS to answer the second, third, and fourth research questions in the first round. Tables (1), (2), and (3) show the data analysis for each questionnaire item with the actual statements. 
Table 12

The analysis the data for the second question with the corresponding items

\begin{tabular}{|c|c|c|c|c|}
\hline No. & Questionnaire items & Average & Std. Dev. & $\%$ \\
\hline 1 & $\begin{array}{l}\text { There is equality between women and men in the number of opportunities for } \\
\text { training and qualification programs in digital art. }\end{array}$ & 3.4 & 0.7 & $85 \%$ \\
\hline 2 & $\begin{array}{l}\text { Art education curricula in public schools and universities are associated with } \\
\text { modern technology to qualify and refine the skills of Saudi women to achieve } \\
\text { the Kingdom's } 2030 \text { vision. }\end{array}$ & 3.7 & 0.9 & $73 \%$ \\
\hline 3 & $\begin{array}{l}\text { There is an abundance of specialized trainers to help women innovate and be } \\
\text { creative in the field of digital art. }\end{array}$ & 3.5 & 1.1 & $71 \%$ \\
\hline 4 & $\begin{array}{l}\text { Saudi universities offer specialized academic programs in the field of digital art } \\
\text { to qualify Saudi girls in this field. }\end{array}$ & 3.4 & 1.1 & $68 \%$ \\
\hline 5 & $\begin{array}{l}\text { Programs and training courses in digital art for women in the various regions of } \\
\text { the Kingdom are available in an adequate form. }\end{array}$ & 3.4 & 1.0 & $68 \%$ \\
\hline 6 & $\begin{array}{l}\text { Saudi women receive the assistance of specialized institutions to hone their } \\
\text { experiences and capabilities through various technical workshops. }\end{array}$ & 3.3 & 1.2 & $65 \%$ \\
\hline 7 & $\begin{array}{l}\text { Virtual education is invested in holding training programs on digital art and the } \\
\text { rehabilitation of Saudi women. }\end{array}$ & 3.3 & 0.9 & $65 \%$ \\
\hline 8 & $\begin{array}{l}\text { Saudi women have experience in the skills of using computers and its } \\
\text { applications in digital art. }\end{array}$ & 3.2 & 0.9 & $64 \%$ \\
\hline 9 & $\begin{array}{l}\text { There are many channels and digital educational platforms that contribute to } \\
\text { helping Saudi women possess various digital art skills and tools. }\end{array}$ & 3.1 & 1.1 & $63 \%$ \\
\hline 10 & $\begin{array}{l}\text { Saudi women participate in scientific lectures and workshops in digital art } \\
\text { conferences and exhibitions to raise the level of their culture in society. }\end{array}$ & 2.7 & 1.2 & $53 \%$ \\
\hline
\end{tabular}

Table 13

The analysis of the data for the third question with the corresponding items

\begin{tabular}{|c|c|c|c|c|}
\hline No. & Questionnaire items & Average & Std. Dev. & $\%$ \\
\hline 1 & $\begin{array}{l}\text { The Saudi family supports women doing digital art to support their capabilities } \\
\text { and increase their economic income. }\end{array}$ & 4.1 & 0.7 & $83 \%$ \\
\hline 2 & $\begin{array}{l}\text { The high prices of hardware and electronic software prevents women from } \\
\text { acquiring them. }\end{array}$ & 4.1 & 0.6 & $83 \%$ \\
\hline 3 & $\begin{array}{l}\text { Business owners prefer to assign men and women equally in the implementation } \\
\text { of digital art works and projects. }\end{array}$ & 3.9 & 0.6 & $77 \%$ \\
\hline 4 & $\begin{array}{l}\text { There are temporary and permanent specific work programs to increase } \\
\text { employment opportunities for Saudi women in digital art projects. }\end{array}$ & 3.6 & 1.2 & $72 \%$ \\
\hline
\end{tabular}




\begin{tabular}{|c|c|c|c|c|}
\hline 5 & $\begin{array}{l}\text { The flexibility of the local labor market allows Saudi women to participate and } \\
\text { work in the areas of digital art. }\end{array}$ & 3.4 & 0.8 & $68 \%$ \\
\hline 6 & $\begin{array}{l}\text { Specialized societies and cultural clubs contribute to training Saudi women in } \\
\text { digital art. }\end{array}$ & 3.4 & 1.1 & $68 \%$ \\
\hline 7 & Women working in digital art can separate homework and work duties. & 3.3 & 1.1 & $65 \%$ \\
\hline 8 & $\begin{array}{l}\text { Women's work in the field of digital art is consistent with the values and customs } \\
\text { of Saudi society. }\end{array}$ & 3.3 & 1.0 & $65 \%$ \\
\hline 9 & $\begin{array}{l}\text { The infrastructure is available to facilitate women working remotely in the areas } \\
\text { of digital art, to increase their contribution to society and to reconcile with their } \\
\text { family duties. }\end{array}$ & 3.1 & 0.8 & $61 \%$ \\
\hline 10 & $\begin{array}{l}\text { Social relationships and family duties affect the reduced ability of Saudi women } \\
\text { to meet the requirements of working in the field of digital art. }\end{array}$ & 2.7 & 1.0 & $55 \%$ \\
\hline
\end{tabular}

Table 14

The analysis the data for the third question with the corresponding items

\begin{tabular}{|c|c|c|c|c|}
\hline No. & Questionnaire items & Average & Std. Dev. & $\%$ \\
\hline 1 & $\begin{array}{l}\text { The community and its institutions provide opportunities for training, education } \\
\text { and work in digital art. }\end{array}$ & 4.3 & 0.7 & $85 \%$ \\
\hline 2 & $\begin{array}{l}\text { The new cultural bodies in the Kingdom take over the management of the } \\
\text { cultural sector with various arts majors and support Saudi women in building } \\
\text { educational programs and providing scholarships. }\end{array}$ & 4.3 & 0.6 & $85 \%$ \\
\hline 3 & $\begin{array}{l}\text { The labor market provides Saudi women with marketing opportunities to work } \\
\text { and develop them. }\end{array}$ & 4.3 & 0.8 & $87 \%$ \\
\hline 4 & $\begin{array}{l}\text { Create new jobs for Saudi women in the filed od digital art by training them at } \\
\text { the educational institutions. }\end{array}$ & 4.6 & 0.8 & $92 \%$ \\
\hline 5 & $\begin{array}{l}\text { Providing job opportunities for Saudi women in the field of digital arts in local } \\
\text { ministries and institutions. }\end{array}$ & 4.7 & 0.6 & $93 \%$ \\
\hline 6 & $\begin{array}{l}\text { Increasing the economic income of women in work in the digital arts by } \\
\text { producing continuous goods and services in this field. }\end{array}$ & 4.5 & 0.8 & $89 \%$ \\
\hline 7 & $\begin{array}{l}\text { Providing scientific and social meetings between employers, specialists, and } \\
\text { those who work in the field of digital arts. }\end{array}$ & 4.5 & 0.6 & $91 \%$ \\
\hline 8 & $\begin{array}{l}\text { Providing links between the public sector and investors, on the one hand, and } \\
\text { specialized societies for the training of women, on the other. }\end{array}$ & 4.5 & 0.9 & $88 \%$ \\
\hline 9 & $\begin{array}{l}\text { Establishing societies specialized in digital arts to support Saudi women in all } \\
\text { regions of the Kingdom of Saudi Arabia }\end{array}$ & 4.5 & 0.6 & $91 \%$ \\
\hline 10 & $\begin{array}{l}\text { Providing Arabic and translate books, references, and electronic platforms in the } \\
\text { field of digital technologies that help Saudi women to self-learn and gain skill. }\end{array}$ & 4.5 & 0.8 & $89 \%$ \\
\hline
\end{tabular}


Identification of important statements in the second round

After the result of the experts' survey of the first round, researchers change the order of items by the most meaningful one. A second survey was designed for this round using the same themes with a new order phrase, and the first theme had ten items. The second theme had nine items, and the third theme had fourteen items. Participants answered questions by choosing between three options: yes, neutral or no. Table (4), (5), and (6) show the analysis of the data for each question with the corresponding items.

Table 15

The analysis of the data for the second research question with the corresponding items

\begin{tabular}{|c|c|c|c|c|}
\hline No. & Questionnaire items & Average & Std. Dev. & $\%$ \\
\hline 1 & $\begin{array}{l}\text { Young Saudi women receive the assistance of specialized institutions to hone } \\
\text { their experiences and capabilities through various technical workshops. }\end{array}$ & 2.7 & 0.5 & $91 \%$ \\
\hline 2 & $\begin{array}{l}\text { There is an abundance of specialized trainers to help young Saudi women } \\
\text { innovate and be creative in the field of digital art. }\end{array}$ & 2.7 & 0.5 & $91 \%$ \\
\hline 3 & $\begin{array}{l}\text { Programs and training courses in digital art are available to young Saudi women } \\
\text { in the various regions of the Kingdom in a sufficient and adequate form. }\end{array}$ & 2.3 & 0.8 & $76 \%$ \\
\hline 4 & $\begin{array}{l}\text { Curricula of art education in general and university education are associated } \\
\text { with modern technology to qualify and refine the skills of young Saudi women } \\
\text { to achieve the Kingdom's } 2030 \text { vision. }\end{array}$ & 2.2 & 0.9 & $73 \%$ \\
\hline 5 & $\begin{array}{l}\text { Saudi universities offer specialized academic programs in the field of digital art } \\
\text { to qualify young Saudi women in this field }\end{array}$ & 2.2 & 0.7 & $73 \%$ \\
\hline 6 & $\begin{array}{l}\text { Young Saudi women participate in scientific lectures and workshops and in } \\
\text { digital art conferences and exhibitions to raise the level of their culture in } \\
\text { society. }\end{array}$ & 2.0 & 0.8 & $67 \%$ \\
\hline 7 & $\begin{array}{l}\text { There are many channels and digital educational platforms that contribute to } \\
\text { helping young Saudi women possess various digital art skills and tools. }\end{array}$ & 2.0 & 0.8 & $67 \%$ \\
\hline 8 & $\begin{array}{l}\text { Young Saudi women have experience in the skills of using computers and its } \\
\text { applications in digital art. }\end{array}$ & 1.7 & 0.7 & $58 \%$ \\
\hline 9 & $\begin{array}{l}\text { Virtual education is invested in holding training programs on digital arts, and the } \\
\text { qualification of young Saudi women in this field. }\end{array}$ & 1.7 & 0.5 & $56 \%$ \\
\hline 10 & $\begin{array}{l}\text { There is equality between women and men in the number of opportunities for } \\
\text { training and qualification programs in digital art in the Kingdom of Saudi } \\
\text { Arabia. }\end{array}$ & 1.6 & 0.5 & $53 \%$ \\
\hline
\end{tabular}

Table 16

The analysis of the data for third research question with corresponding items

\begin{tabular}{|c|c|c|c|c|}
\hline No. & Questionnaire items & Average & Std. Dev. & $\%$ \\
\hline 1 & $\begin{array}{l}\text { 1.The infrastructure is available to facilitate women working remotely in } \\
\text { the areas of digital art, to increase their contribution to society and to } \\
\text { reconcile with their family duties. }\end{array}$ & 3.0 & - & $\begin{array}{c}100 \\
\%\end{array}$ \\
\hline 2 & $\begin{array}{l}\text { 2.Business owners prefer to assign men and women equally in the } \\
\text { implementation of digital artworks and projects. }\end{array}$ & 3.0 & - & $\begin{array}{c}100 \\
\%\end{array}$ \\
\hline
\end{tabular}




\begin{tabular}{|c|c|c|c|c|}
\hline 3 & $\begin{array}{l}\text { 3.Women working in digital art can separate house work and work } \\
\text { duties. }\end{array}$ & 2.9 & 0.4 & $96 \%$ \\
\hline 4 & $\begin{array}{l}\text { 4. Specialized societies and cultural clubs contribute to training the Saudi } \\
\text { girl in digital arts. }\end{array}$ & 2.5 & 0.5 & $84 \%$ \\
\hline 5 & $\begin{array}{l}\text { 5.There are temporary and permanent specific work programs to } \\
\text { increase employment opportunities for Saudi women in digital art } \\
\text { projects. }\end{array}$ & 2.5 & 0.7 & $82 \%$ \\
\hline 6 & $\begin{array}{l}\text { 6. The flexibility of the local labor market allows young Saudi women to } \\
\text { participate and work in the areas of digital art. }\end{array}$ & 2.4 & 0.7 & $80 \%$ \\
\hline 7 & $\begin{array}{l}\text { 7.The high prices of hardware and electronic software prevents young } \\
\text { Saudi women from getting to own them. }\end{array}$ & 2.3 & 0.9 & $78 \%$ \\
\hline 8 & $\begin{array}{l}\text { 8. Young Saudi women's work in the field of digital art is consistent with } \\
\text { the values and customs of Saudi society. }\end{array}$ & 1.9 & 0.8 & $62 \%$ \\
\hline 9 & $\begin{array}{l}\text { 9.The Saudi family supports women doing digital art to support their } \\
\text { capabilities and increase their economic income. }\end{array}$ & 1.7 & 0.7 & $58 \%$ \\
\hline
\end{tabular}

Table 17

The analysis the data for the third research question with corresponding items

\begin{tabular}{|c|c|c|c|c|}
\hline No. & Questionnaire items & Average & Std. Dev. & $\%$ \\
\hline 1 & $\begin{array}{l}\text { Establishing societies specialized in digital arts to support Saudi women in all } \\
\text { regions of the Kingdom of Saudi Arabia. }\end{array}$ & 3.0 & - & $100 \%$ \\
\hline 2 & $\begin{array}{l}\text { Providing Arabic and translated books, references, and electronic platforms in } \\
\text { the field of digital technologies that help Saudi women to self-learn and gain } \\
\text { skill. }\end{array}$ & 2.9 & 0.4 & $96 \%$ \\
\hline 3 & $\begin{array}{l}\text { That the new cultural organizations in the Kingdom manage the cultural sector } \\
\text { to support Saudi women in building educational programs and offering } \\
\text { scholarships }\end{array}$ & 2.9 & 0.4 & $96 \%$ \\
\hline 4 & $\begin{array}{l}\text { Providing links between the public sector and investors on the one hand, and } \\
\text { specialized societies for the training of women on the other hand. }\end{array}$ & 2.9 & 0.4 & $96 \%$ \\
\hline 5 & $\begin{array}{l}\text { Providing scientific and social meetings between employers, specialists, and } \\
\text { those in charge of work in the field of digital arts. }\end{array}$ & 2.9 & 0.4 & $96 \%$ \\
\hline 6 & $\begin{array}{l}\text { Establishing an electronic platform for digital art to support Saudi women by } \\
\text { providing and Arabizing electronic programs and marketing their artistic } \\
\text { product. }\end{array}$ & 2.9 & 0.5 & $96 \%$ \\
\hline 7 & $\begin{array}{l}\text { Organizing the Saudi digital art market in a way that increases the attractiveness } \\
\text { of Saudi female creators towards it }\end{array}$ & 2.8 & 0.4 & $93 \%$ \\
\hline 8 & $\begin{array}{l}\text { Work to establish a special arts and design authority such as the Saudi } \\
\text { Commission for Health Specialties or Saudi engineers and support them to } \\
\text { organize the Saudi art market. }\end{array}$ & 2.8 & 0.4 & $93 \%$ \\
\hline 9 & Increasing the economic income of women in work in the digital arts by & 2.7 & 0.5 & $91 \%$ \\
\hline
\end{tabular}




\begin{tabular}{|c|c|c|c|c|}
\hline & producing continuous goods and services in this field & & & \\
\hline 10 & $\begin{array}{l}\text { Providing job opportunities for Saudi women in the field of digital arts in local } \\
\text { ministries and institutions. }\end{array}$ & 2.7 & 0.5 & $91 \%$ \\
\hline 11 & $\begin{array}{l}\text { The labor market provides Saudi women with marketing opportunities to work } \\
\text { and develop them. }\end{array}$ & 2.7 & 0.6 & $91 \%$ \\
\hline 12 & $\begin{array}{l}\text { Create new jobs in the fields of digital arts through academic and training } \\
\text { majors in educational and training institutions. }\end{array}$ & 2.7 & 0.6 & $89 \%$ \\
\hline 13 & $\begin{array}{l}\text { The community and its institutions provide opportunities for training, education } \\
\text { and work in digital arts. }\end{array}$ & 2.7 & 0.6 & $89 \%$ \\
\hline 14 & $\begin{array}{l}\text { Holding permanent and seasonal exhibitions, biennials and competitions in } \\
\text { digital art. }\end{array}$ & 2.7 & 0.5 & $89 \%$ \\
\hline
\end{tabular}

\section{iv. DISCUSSION AND RESULTS}

-In order to identify the general trend in the use of digital arts by Saudi women, the survey data indicate that the graduates of the Art Education Department show a positive trend for work in the field of digital art by $82.9 \%$ compared to $17.1 \%$, which indicates a positive trend for working in the field of digital art. This result confirms the rapid response to the survey conducted by most of the female students while teaching digital art courses, as well as the national transformation in the Kingdom of Saudi Arabia, and the emphasis on the importance of empowering women in all fields..

- to identify the responses of the study sample towards societal contributions that enable Saudi young women to obtain adequate income from digital arts, the responses of the study sample in the first round indicated that there is equality between women and men in the number of training opportunities and rehabilitation programs in digital art. $85 \%$ of the participants agreed with this which is $32 \%$ more than the results of the second round. The abundance of professional trainers to help girls innovate and create in the field of digital arts is seeing a significant rise from $73 \%$ to $91 \%$ in the second round. The importance of art education curricula in public schools and universities is related to modern technology to qualify and refine the skills of women that have been achieved and to maintain a constant score of $73 \%$ in both rounds. In general, there was an increase in the skills needed in the second round compared to the first round. The average significance of feedback from community contributions that enable women to earn adequate income and become selfreliant was a constant standard deviation, from 0.5 to 0.9 , compared to the first round, with a standard deviation ranging from 0.7 to 1.2 .
-In order to know the responses of the study sample about the challenges that hinder the work of Saudi young women and their empowerment in the field of digital arts, the sample responses indicate the extent of support that women participating in art receive from their families and the preventive behavior of hardware and software prices of the highest degree of importance. After that, they have the lowest standard deviation of 0.6. On the other hand, social relations and family duties and their extra nature and how they affect women got the least importance in the first round. With a standard deviation of 1.1, an average performance score of 3.4 is observed at this stage. The other aspects that were of near medium importance were the last point in the first round, which is the infrastructure available to facilitate remote work for women in the fields of digital art, to increase their contribution to society and reconcile work and family duties. In the second round, the available infrastructure to facilitate women's work remotely in the fields of digital art to increase their contribution to society and reconcile with their family duties, and the idea that business owners prefer to assign men and women equally in implementing artworks and digital projects were two elements of $100 \%$ importance. Each participant awarded him a score of 3 , which means he had no standard deviation.

-In order to identify the most important economic benefits that can be gained from empowering young Saudi women in digital arts from the point of view of the study sample, their responses indicated the importance of creating new job opportunities in the field of digital art through academic and training specializations in educational and training institutions and providing job opportunities for women in the field of digital skills in Ministries and local institutions emerged as options with the highest percentages of respondents, with scores of $92 \%$ and $93 \%$ in the first round, respectively. Likewise, providing scientific and social meetings between employers, specialists and workers in the field of digital art and creating societies specializing in digital skills to support women in all regions had a score of $91 \%$ in the first round, 
which means that it was important. For respondents. With standard deviations of 0.7 and 0.6 , the two statements were as follows: Society and its institutions provide opportunities for training, education and work in digital art and new cultural bodies manage the cultural sector with various artistic specializations and support women in building educational programs and providing scholarships. These two statements had a significance score of $85 \%$ among the first round participants. In addition, the standard deviation in the first round ranged from 0.6 to 0.8 compared to 0.4 to 0.6 in the second round.

\section{v. CONCLUSION}

Presenting the Delphi survey results helped determine the dimensions of empowering Saudi young women in digital art activities in light of the development strategy within the framework of the Kingdom's 2030 Vision. The study used the Delphi technique questionnaire with two rounds as part of the data collection tools. In this study, three important themes were explored: (a)the reality of trends towards digital art for Saudi women, (b) the community contributions that enable women to obtain an appropriate income and depend on themselves, and (c)the obstacles that hinder the work and empowerment of women in the field of digital arts, the most important economic benefits that can be derived from empowering women in the field of digital art. The results of the study suggest that young Saudi women can be empowered through the use of digital art in Saudi Arabia. the Saudi society has been described how undergoing change since 2016 under the rule of King Salman bin Abdulaziz and following Crown Prince's declaration of Saudi Vision 2030 with its focus on women's rights reform [25]. In other words, Saudi women have become visible and supported by the government, not only in digital art, but in all fields, where Saudi women are currently living in an unprecedented phase of empowerment, according to the statements of the Crown Prince to the Saudi Press Agency, where Prince Muhammad bin Salman compared the situation of Saudi women In the past and during the current days, when she could not travel without a permit, attend sporting and cultural events, are not permitted to drive a car, do not practice a lot of work, or finish her cases without a mahram, and she has suffered from that for decades, but at the present time the government OF The Kingdom of Saudi Arabia Worked to empower women in the field of work and personal status, and today it is effectively a partner for the Saudi man in the development of the homeland without discrimination, while providing opportunities for her to lead the development process in the country in the broadest sense, for example, the rate of women's participation in the labor market has doubled from $17 \%$ To $31 \%$, and diversified areas of work, and business An increasing number of young Saudi women have achieved success due to the Saudi Vision 2030 with gender reform policiesLimitations and future research Study limitations can exist due to constraints on research methodology that may impact the findings of the study. There are limitations inherent in the method itself; for example, researchers may ask questions that participants cannot understand or certain statements may not be understood correctly. Also, the fact that the sample was composed by $60 \%$ of male participants may affect the results since there were fewer female participants. Future studies that gather qualitative data to explore the experiences of young Saudi women in terms of empowerment following the new reform policies of Saudi Vision 2030 will enable a more thorough investigation of this issue. Such studies may highlight nuanced experience of international women in the workforce. Additionally, further quantitative research using a larger sample is needed to determine whether the implications of this study can be generalized to a wider population. This survey study was limited to a small number of participants in Saudi Arabia. Furthermore, as the data were gathered from one site only, the experiences of these participants may be dependent on similar characteristics shared among the respondents. Future research would benefit from a cross-institutional analysis, as well as gathering data from a variety of international higher education contexts.

\section{Acknowledgments:}

The authors extend their appreciation to the Deputy for research and Innovation, Ministry of Education in Saudi Arabia (initiative of social sciences) for funding this research work through the project number SS-153 (through the initiative of social sciences).

\section{Funding:}

Ministry of Education in Saudi Arabia for funding this research work through the project number SS-153 (through the initiative of social sciences number of the contract).

\section{Compliance with Ethical Standards:}

- We have no conflicts of interest to disclose.

\section{References}

[1] N. Saqib, P. Aggarwal, S. Rashid, (2016). Women Empowerment and Economic Growth: Empirical Evidence from Saudi Arabia. Advances in Management \& Applied Economics, 6(5). http://www.scienpress.com/Upload/AMAE $\% 2 \mathrm{fVol} \% 206$ 5 5.pdf

[2] D. Xing-Yan, L. Zhong (2020). Research on the Intergenerational Flow of Migrant Workers' Education, WSEAS Transactions on Business and Economics, ISSN / E-ISSN: 1109-9526 / 2224-2899, Volume 17, Art. 74, pp. 759-768.

[3] A. Ribaj, Manuela Me?e, Valbona Cinaj, Ilda Kadrim, (2020). Issues Related to Financial Education of Youth in a Developing Country (The Case of Albanian Youth), WSEAS Transactions on Business and Economics, ISSN / E-ISSN: 1109-9526 / 2224-2899, Volume 17, , Art. 16, pp. 140-152.

[4] A. Alzahrani (2017). Markets and language policy in Saudi Arabia: how the English language can contribute to the success of the Saudi vision 2030. International Journal of English Language and Linguistics Research, 5(6), 1 - 12. https:/www.researchgate.net/publication/329727456 TH 
E EFFECTIVE USE OF YOUTUBE VIDEOS FOR TEACHING ENGLISH LANGUAGE IN CLASSROO MS AS SUPPLEMENTARY MATERIAL AT TAIBA H_UNIVERSITY_IN_ALULA

[5] A. Topal, (2019, September). Economic reforms and women's empowerment in Saudi Arabia. In Women's Studies International Forum (Vol. 76, p. 102253). Pergamon. https://doi.org/10.1016/j.wsif.2019.102253

[6] A. Basaffar, L. S. Niehm \& R. Bosselman (2018). Saudi Arabian women in entrepreneurship: Challenges, opportunities and potential. Journal of Developmental Entrepreneurship, 23(02). 1850013.https://doi.org/10.1142/S1084946718500139

[7] A. Omar (2020). Economic Empowerment of Saudi Women: Dimensions and Constraints. Umm Al-Qura, Journal for Social Sciences, 2 (12), 3-41.

[8] Kh. Gharabi, and S. Makhlouf, (2019). Empowering Arab women in the economic and political sphere: Algeria, Saudi Arabia, and Morocco as an example. Taheri Muhammad University, College of Economic Sciences and Business Sciences, 3 (5), 159-170

[9] K, Obaid (2019): Digital Art. Our Culture Magazine, Ministry of Culture, Public Cultural Relations Department

[10] Y. Al-Saggaf, (2004). The effect of online community on offline community in Saudi Arabia. The Electronic Journal of Information Systems in Developing Countries, 16. https://doi.org/10.1002/j.16814835.2004.tb00103.x

[11] S. I. Islam, (2014). Saudi women: Opportunities and challenges in science and technology. Education Journal, 3(2), 71-78. http://dx.doi.org/10.11648/j.edu.20140302.15

[12]I. S. Al-Halabi, (2020). Empowering Saudi women in light of the Kingdom's vision 2030 and its reflection on family stability. Journal of Arts, Literature, Humanities and Sociology, Emirates College of Educational Sciences, 48, 338-362.

[13]A. Alasgah, E , Rizk (2020). Empowering Saudi women in the tourism and management sectors according to the Kingdom's 2030 vision. Journal of Sustainable Finance \& Investment. https://doi.org/10.1080/20430795.2021.1874217

[14] L. F. Abul-Naga, (2019). The role of digital technologies in the production of conceptual photography. Journal of Architecture, Arts and Humanities, Arab Society for Civilization and Arts, 322-343

[15] S. Abu Khashaba, , I. Al-Senour, , W. Ahmed, L. Safi, (2018). 3D design programs and their impact on digital sculpture. The EMSA Association's Scientific Journal of Education Through Art, 15 (16), 356-378

[16] Van Ginhoven, S., \& Rasterhoff, C. (2019, September). Art Markets and Digital Histories. In Arts (Vol. 8, No. 3, p. 105). Multidisciplinary Digital Publishing Institute. https://doi.org/10.3390/arts8030105

[17] R. Muzaffar (2012). Digital image technologies and their role in the transformations of contemporary global painting. Unpublished MA Thesis, University of Baghdad, College of Fine Arts.

[18] W. M. Samaha (2017). Creative vision of abstract digital arts and utilizing them in artistic formulations to enrich the decorative aspect of contemporary women's fashion. Journal of Specific Education Research, Egypt, 47, 371 400.

[19]A.N. Ahmed (2016). Multimedia as an introduction to the creation of formal variables on the elements and their role in formulating the composition of the digital painting. Journal of Specific Education Research, 42, 1114-1135.

[20]E. Sidorova (2019, September). The Cyber Turn of the Contemporary Art Market. In Arts (Vol. 8, No. 3, p. 84). Multidisciplinary Digital Publishing Institute. https://doi.org/10.3390/arts8030084

[21] Y . Zaki, A. Al Muwali, , \& N. Mahdi (2018). Infusing Creativity and Technology through Repurposing Existing Digital Tools and Social Media Apps for Educational Purposes. In Interactivity, Game Creation, Design, Learning, and Innovation (pp. 319-330). Springer, Cham. https://doi.org/10.1007/978-3-030-06134-0_36

[22] Wang, T. W. (2018). Empowering Art Teaching and Learning With iPads. Art Education, 71(3), 51-55. https://doi.org/10.1080/00043125.2018.1436353

[23]N. Alsuwaida (2018). Disruptive Innovation in the Fashion Design Classroom with Learning Technology and Social Media. New Mexico State University. Las Cruces: USA.

https://search.proquest.com/openview/1b93dbfb7ff836314 069d70d88665c21/1?cbl=18750\&diss=y\&pqorigsite $=$ gscholar

[24] D. Song, T. Lee, \& Y. J. Kim (2018, May). Artistic pen drawing on an arbitrary surface using an impedancecontrolled robot. In 2018 IEEE International Conference on Robotics and Automation (ICRA) (pp. 4085-4090). IEEE. https://doi.org/10.1109/ICRA.2018.8461084

[25]Eum, I. (2019). "New Women for a New Saudi Arabia?" Gendered Analysis of Saudi Vision 2030 and Women's Reform Policies. Asian Women, 35(3). https://doi.org/10.14431/aw.2019.09.35.3.115

\section{Creative Commons Attribution License 4.0 (Attribution 4.0 International, CC BY 4.0)}

This article is published under the terms of the Creative Commons Attribution License 4.0

https://creativecommons.org/licenses/by/4.0/deed.en_US 